\title{
Higher Secondary Learners' Effectiveness towards Web Based Instruction (WBI) on Chemistry
}

\author{
A. Sudha, S. Amutha* \\ Department of Educational Technology, Bharathidasan University, India
}

Copyright (C) 2015 by authors, all rights reserved. Authors agree that this article remains permanently open access under the terms of the Creative Commons Attribution License 4.0 International License

\begin{abstract}
Web-based training is becoming a phenomenon in education today because of its flexibility and convenience, it is vitally important to address those issues that adversely impact retention and success in this environment. To generate principles of effective asynchronous web-based materials specifically applicable for secondary level students based upon the perceptions of those who have developed effective web-based content. The development and formulation of an instructional approach for effective use of web-based learning is generally in science and particularly in chemistry. Web-based instruction is more appropriate to be used as a supplementary tool in learning process .WBI enables the learning process interesting and more meaningful since it provides multisensory experience to the students. The paradigm shift from student centered to learner-centered education has emphasized the use of WBI. Students have to use a variety of strategies in learning to accomplish classroom academic tasks. WBI help students and teachers and also institutions in improving overall learning process. The authorities need to focus on the integration between the technology and the pedagogical practices. Web-based instruction created by Blackboard was well suited to the students' needs. Learners' perspectives toward online learning have offered valuable insights into a way to make the connection between the teachers goal and learners need while learning in a Web-based instructional environment. This paper attempts to find out the higher secondary learners' effectiveness towards web-based instruction on chemistry. Experimental method was adopted in this study. Samples were divided into control and experimental groups. Control group was taught by traditional method and experimental group with web based instruction. Pre-test and post-test was administered to both the groups. The findings of the study reveals that there is no significant mean difference between the achievements of pre-test and post-test scores taught by traditional method and there is significant mean difference between the achievements of pre-test and post-test scores in the web based instructional method since it provides multisensory experience to the students.
\end{abstract}

Keywords Web Based Instruction, Effectiveness, Chemistry, Higher Secondary Learners

\section{Introduction}

Ha Jin Hwang [7] Web Based Instruction (WBI) is becoming more important in the field of education as the education paradigm is changing, shifting the classroom initiatives from teachers to students. The paradigm shift requires new instruction methods which can effectively adopt the rapid change of the education environment. Kian Sam Hong [10] it has been found that student-instructor interactions and group dynamics affected on students' satisfaction with and learning from the web-based course. Annamma George [1] web based instruction is an effective teaching strategy for developing scientific skills like Reporting, Interpretation, Reasoning and Problem Solving especially for the higher secondary students. Katherine Pang [8] Interactivity is an important to deliver effective web-based professional development programs. Clark [5] wbi may be more efficient or less costly than other vehicles, it is the learning dimensions that will determine its ultimate effectiveness and worth. Zeynep Tatli \& et al. [18] the virtual laboratory software was effective as real as chemistry laboratories. Bude Su \& et al. [3] the technologies used and instructional activities that require sophisticated technical skills that need a significant amount of time to learn how to use them effectively. According to Yi-Cheng Chen \& et al. [17] web based instruction program directors, system developers and instructors can make the best of this WBI instrument for understanding of student's inclinations and take necessary corrective actions to improve. Franklin. R. Koontzand \& et al. [6] there was a call by teaching faculty and professional instructional designers for a specific model dedicated to designing Web-based courses. Technical Report [14] emerging trends in tertiary education have seen a shift in focus from teacher- centred to learner- centred education and an increase in the use of web-based learning environments in 
teaching programmes. Which methods and strategies should adapt the characteristic of web- based environment. The purpose of this study therefore was to find out the higher secondary learners' effectiveness towards web-based instruction on chemistry in order to proffer useful suggestions.

\section{Rationale of the Study}

The knowledge of using WBI method are essential for teacher and students. Such knowledge helps them to develop a better understanding of the chemistry concept:

Understanding enables the teacher,

- To acquire necessary skills in learning

- To develop a positive attitude

- To develop interest in learning

- To guide the learners growth and development

In the modern education technology, the web based teaching and learning has been found to be more effective and time saving. The web resources plays the most crucial role in making the web based teaching and learning and it is more functional and effective. Therefore the WBI method is more important.

Objectives

The following are the objectives of this study

- To develop and validate web-based instruction in learning chemistry at higher secondary level.

- To find out the relationship between the conventional teaching method and WBI method in organic chemistry at higher secondary level students.

- To determine the effectiveness of the web based instruction with the performance of learner's in chemistry.

- To identify the higher secondary level learners learning difficulties in chemistry subject.

- To evolve recommendations for policy making.

\section{Methods and Materials}

Experimental method was adopted in this study. Pre-test was administered in order to find out the entry behaviour of the students towards WBI in chemistry. Sample consists of 58 chemistry students of which 24 of control group and another 24 for experimental group. The investigator taught the topic "Purification of organic compounds" in the following aspects nomenclature, formulas, functional groups, structures, characterization and reactions using many related websites in chemistry, to acquire information. Opportunity was given to the students to explore the websites at their own pace. Post test was conducted in order to find out the effectiveness of WBI. An achievement test was prepared by the investigator with 25 questions. Scores of the achievement test ranges from $0-20$. "SPSS" software 16.0 version was used in the statistical analysis.

\section{Hypothesis 1}

Control group and Experimental group higher secondary level students do not differ significantly in the pre-test.

Table 1. Comparison of mean scores of Control group and Experimental group in the Pre- test.

\begin{tabular}{|c|c|c|c|c|c|c|c|}
\hline \multirow{3}{*}{$\begin{array}{l}\text { Pre- } \\
\text { test }\end{array}$} & \multirow{3}{*}{$\begin{array}{l}N \\
24\end{array}$} & \multicolumn{2}{|c|}{ Control group } & \multicolumn{2}{|c|}{$\begin{array}{l}\text { Experimental } \\
\text { group }\end{array}$} & $\mathrm{t}$-value & Sig \\
\hline & & Mean & SD & Mean & $\mathrm{SD}$ & 2531 & 015 \\
\hline & & 10.79 & .833 & 11.33 & .637 & & \\
\hline
\end{tabular}

It can be seen from table. 1 that the higher secondary level chemistry students mean score in control group is (10.79) and

Experimental group is (11.33). Their ' $t$ ' value is 2.958 which is significant at 0.01 level of significance.

\section{Hypothesis 2}

Control group and Experimental group higher secondary level students do not differ significantly in the post-test.

Table 2. Comparison of mean scores of Control group and Experimental group in the Post-test

\begin{tabular}{|l|c|c|c|c|c|c|c|}
\hline \multirow{2}{*}{$\begin{array}{c}\text { Post } \\
\text {-test }\end{array}$} & \multirow{2}{*}{$\mathrm{N}$} & \multicolumn{2}{|c|}{ Control group } & \multicolumn{2}{c|}{$\begin{array}{c}\text { Experimental } \\
\text { group }\end{array}$} & t-value & Sig \\
\cline { 2 - 8 } & & Mean & $\mathrm{SD}$ & Mean & $\mathrm{SD}$ & & \\
\cline { 2 - 8 } & 24 & 18.33 & 1.404 & 20.25 & 1.073 & & .000 \\
\hline
\end{tabular}

' $\mathrm{T}$ ' test of table.2 indicated that higher secondary level chemistry students of control group $(\mathrm{N}=24)$ and experimental group $(\mathrm{N}=24)$ differ significantly in the post-test mean scores at 0.01 level of significance. The post-test mean score of experimental group $(\mathrm{M}=20.25)$ is less than that of the post -test mean score of control group $(\mathrm{M}=18.33)$.As far as the two groups are concerned, there is a significant difference seen (S.D of experimental group is 1.073and S.D of control group is 1.404).Also a high positive mean score is obtained between the experimental group and the control group. Hence it is inferred that the WBI is to influence more in learning of chemistry. The mean scores of Control group which indicated that WBI helped the higher secondary level students to improve their learning capacity in chemistry. This finding is also supported by Cheng-Yao Lin [4] who has stated that WBI was positively influenced in learning. Another study conducted by Mriganka Narayan Das [11] reported that there was a positive improvement in Higher Secondary Learning through WBI. Hence the enhancement in chemistry proved that the using of WBI was effective.

\section{Hypothesis 3}

There is no significant difference in the mean score between girls and boys higher secondary students in the Post-test. 
Table 3. Comparison of mean scores in the post-test based on gender

\begin{tabular}{|c|c|c|c|c|c|c|c|c|}
\hline \multirow{2}{*}{$\begin{array}{c}\text { S. } \\
\text { No }\end{array}$} & \multirow{2}{*}{ Group } & \multirow{2}{*}{$\mathrm{N}$} & \multicolumn{2}{|c|}{ Pre-test } & \multicolumn{2}{|c|}{ Post-test } & \multirow{2}{*}{ t-value } & \multirow{2}{*}{ Sig } \\
\cline { 4 - 7 } & & & Mean & SD & Mean & SD & & \\
\hline 1. & Male & 26 & 11.23 & .863 & 19.35 & 1.495 & \multirow{2}{*}{.259} & \multirow{2}{*}{.797} \\
\hline 2. & Female & 22 & 10.86 & .639 & 19.23 & 1.688 & & \\
\hline
\end{tabular}

It is observed from the table- 3 that ' $t$ ' test indicates that male students $(\mathrm{N}=26)$ differ significantly in the pre-test and the post-test at 0.01 level of significance. The mean scores of the post-test $(\mathrm{M}=19.35)$ is greater than that of pre-test $(\mathrm{M}=11.23)$. The ' $\mathrm{t}$ ' test score indicates that female students $(\mathrm{N}=22)$ differ significantly in the pre-test and the post-test at 0.01 level of significance. The mean score of the post-test $(M=19.23)$ is greater than that of pre-test $(M=10.86)$.From this it is inferred that male students performed better than the female students in using WBI for learning the topic 'Purification of Organic Compounds' in chemistry. Since other studies done in the WBI had concentrated mainly on other variables like location of the learners, Medium of instruction, etc., There was no supporting evidence found in reviews to strengthen this finding. However, this study shows male has performed well. It may be due to the geographical background and economical status of the sample of the study.

Findings of the Study

The following are the findings of the present study

1. Higher secondary of control group and experimental group differ significantly in the pre-test.

2. Higher secondary of control group and experimental group differ significantly in the post-test.

3. Male higher secondary students outperformed the female students in terms of their achievement in chemistry.

\section{Discussion}

Sawant \& et al. [13] found a positive effect on implementation of web based education in their study. Present study also corroborate with that result. Yavuz Erdogan \& et al. [16], Uschi Felix [15] studies revealed that web based education have positive effects on the academic achievement. The present investigation conceptualized from the findings that effectiveness of WBI influenced the achievement in chemistry among higher secondary level students. According to Annie Kavitha [2] web-based learning students performed better than the traditional learning students. Present studies also go in line with these result. Khachakrit Liamthaisong \& et al. [9] revealed that Students were extremely satisfied after learning through the web. They have gained more knowledge in the subject. In the present study learning outcomes of higher secondary learners were high.

\section{Recommendations for Policy Making}

Research in general and educational research in particular should be committed to contribute for further policy decisions on the basis of the findings. The present study leads to the following recommendations.

- Providing them with fresh approaches to teaching familiar topics such as physical, organic, and inorganic chemistry.

- From the findings of the study, the higher secondary students learn better by the use of WBI method in related lessons.

- Hence there is a need to change the teaching methods in higher secondary level.

- Using the WBI and related to the websites in lessons should be incorporated in backside text-book.

- Proper weightage should be provided in the practical examination to students who are using technology.

- This study witnessed acceptable level of WBI method among the higher secondary level students, serious considerations are needed for the integration of WBI components while formulating higher secondary curriculum.

- Training the higher secondary school teachers in WBI be made compulsory and professional credits can be awarded to encourage the higher secondary school teachers to use WBI in their routines.

- Developing teachers' confidence in using modern gadgets as a teaching tool.

- The teachers of all the higher secondary school must be offered training programmes for developing WBI method of students for learning in chemistry.

- Steps must be taken to increase the availability of technology facilities in higher secondary school.

- Students should be trained to handle technology based method in Physical, Organic, and Inorganic chemistry.

- Teachers should continuously make the use of the WBI method.

\section{Suggestions for further research}

Based on the findings of the present study, the following suggestions are given for further research.

- A study may be conducted to find out the factors that influence the learning style and achievement.

- It is suggested to undertake micro-level and local specific area studies in the WBI at higher secondary level.

- The present study has taken only one dependent variable effectiveness of WBI.A study may be attempted to find out the effectiveness of WBI with some other dependent variables like anxiety, problem solving ability, comprehension of the equations etc. 


\section{Conclusions}

WBI method is meant not only for the present generation but also for posterity. The WBI method help in stronger registry and longer retention of the content learnt. This method of learning does not substitute a teacher, but it complements the teacher in his /her teaching process.WBI method is one of the latest technologies integrated in education. It helps to cut across the boundaries of apace and time .It takes the specialist to the learners' desk.

Web technology undoubtedly has offered many benefits for the learners and instructors, however, the pitfalls need careful consideration in the design of the learning environment O'Donoghue \& et al. [12]

Technology is never a substitute for good teaching but traditional classroom teaching may not prove worthy in the present scenario and without skilled instructors, no electronic delivery can achieve good results.

The present study has been undertaken with a view to providing a status report of the effectiveness of WBI in chemistry at higher secondary level in selected schools in Ariyalur district. The findings and conclusion of the study can be generalized to greater extend. The concept of study aims at the, access to the WBI method, knowledge of using WBI method in related to the chemistry lessons is inseparable an unavoidable in every ones' life especially for higher secondary school students.

\section{REFERENCES}

[1] Annamma George. (2013). "Effectiveness of web based instruction in learning scientific skills among higher secondary students", Ph.D thesis, Department Of Education, Karunya University, Coimbatore. Available at http://shodhganga.inflibnet.ac.in.

[2] Annie Kavitha, L. (2013). "Effectiveness of Web-Based Instruction and Traditional Class Room Instruction in Learning of Mathematics", International Journal of Innovative Research \& Development, Vol.2, No.11, pp.457-460.

[3] Bude Su, Curtis J, Bonk, Richard J, Magjuka, Xiaojing Liu, and Seung -Hee Lee. (2005). "The importance of interaction in web-based education: A program - level case study of online MBA courses", Journal of Interactive Online Learning, Vol. 4, No.1, pp.1-19.

[4] Cheng-Yao Lin. (2009). “A comparison study of web-based and traditional instruction on preservice teachers' knowledge of education: A program - level case study of online MBA courses", Journal of Interactive Online Learning, Vol. 4, No.1, pp.1-19.

[5] Clark, R.E. (1994). "Media will never influence learning", Educational Technology Research and Development, Vol.4, No.2, pp.21-29.
[6] Franklin. R. Koontz and Hongqin Li Daniel P. Compora. (2006). "Designing Effective Online Instruction A Handbook for Web-Based Courses", Rowman and Littlefield Education Lanham, Marylfand, Toronto, Oxford. Available at http://chapters.rlpgbooks.com/15/788/1578863864ch1.

[7] Ha Jin Hwang. (2011). "Design of an Effective Learning Evaluation Component in Web-Based Instruction", International Journal of Multimedia and Ubiquitous Engineering, Vol.6, No.4, pp. 1-12.

[8] Katherine Pang. (2009). "Video-Driven Multimedia, Web-Based Training in the Corporate Sector: Pedagogical Equivalence and Component Effectiveness", International Review of Research in Open and Distance Learning, Vol.10, No.3, pp.1-14.

[9] Khachakrit Liamthaisong, Sangkom Pumipuntu, and Sanit Kayapard. (2011). "Efficiency and Effectiveness index of Web-Based Instruction Blended Learning in the Basic Design Course of undergraduate students", Medwell Journals, Vol.6, No.5, pp.375-378.

[10] Kian-Sam Hong. (2002). "Relationships between students' and instructional variables with satisfaction and learning from a Web-based course, Internet and Higher Education, Vol.5, pp.267-281.

[11] Mriganka Narayan Das. (2015). "Effectiveness of the web-based learning in secondary school education", International Journal of Informative \& futuristic Research, Vol.2, No.8, pp.2456-2461.

[12] O'Donoghue, J. Singh, G. and Dorward, L. (2001). "Virtual education in universities: a technological imperative", British Journal of Educational Technology, Vol.32, No.5, pp.511-523.

[13] Sawant, B. S. and Shinde S.P. (2012). "A study of Effect of Web-Based Education Environment in Schools: With special reference to Satara District", International Journal of Soft Computing and Engineering, Vol.1, pp.42-44.

[14] Technical Report. (2006). "Theoretical foundations of Web-based learning environment pedagogy", Computing Education Research Group.1-23. Available at http://cerg.infotech.monash.edu.au/techreps/2006/tr-2006-1. pdf.

[15] Uschi Felix. (2001). "A multivariable analysis of students experience of web based learning", Australian Journal of Educational Technology, Vol.17, No.1, pp.21-36.

[16] Yavuz Erdogan, Servet, Bayram, and Levent Deniz. (2008). "Factors that influence academic achievement and attitudes in web based education", International Journal of Instruction, Vol.1, No.1, pp.31-48.

[17] Yi-Cheng Chen, Yi-Chien Lin, Ron Chuen Yeh, and Shi-Jer Lou. (2013). "Examining factors affecting college students' intention to use web-based instruction systems: towards an integrated model", TOJET: The Turkish Online Journal Of Educational Technology, Vol.12, No.2, pp.111-121.

[18] Zeynep Tatli, and Alipasa Ayas. (2013). "Effect of a Virtual Chemistry Laboratory on Students' Achievement", Educational Technology \& Society, Vol.16, No.1, pp. 159-170. 